\title{
Peran Sektor Pemerintah dan Swasta dalam Perkembangan Destinasi Wisata di Kabupaten Pulau Morotai
}

\author{
Enggar Dwi Cahyo', Wiendu Nuryanti ${ }^{2}$ \\ ${ }^{1}$ Mahasiswa Magister Arsitektur Konsentrasi Pariwisata Departemen \\ Arsitektur dan Perencanaan Fakultas Teknik Universitas Gadjah Mada \\ Email: enggar.dwi.cahyo@mail.ugm.ac.id \\ ${ }^{2}$ Dosen Magister Arsitektur Departemen Arsitektur dan \\ Perencanaan Fakultas Teknik Universitas Gadjah Mada \\ Email: Wiendu@gmail.com
}

\begin{abstract}
Morotai tourism destination is located in North Molucas Province and directly bordering with Philippines. Morotai tourism destination is one of the ten national priority tourism destination of the Republic Indonesia. Kabupaten Pulau Morotai also has one area that is used as a Special Economic Zone based on the development of tourism industry. Tourism development in this region involves many institutions, both from the government sector and from the private sector. This research was proposed to find out about: (1) Fnding out about the role of public and private sector in the development of Morotai tourism destination, (2) Finding out the impact of all programs which run by all sector for the Morotai tourism destination area.

This study uses a qualitative approach with primary data collection using data collection techniques of observation, interviews, and institutional surveys to be able to explore the phenomena that occur at the research location. Interview respondents were determined based on purposive sampling with the selection of respondents based on their respective capacities in the development of tourism destination in Kabupaten Pulau Morotai and supported by secondary data that was deemed appropriate to the research context. Data analysis techniques used descriptive analysis techniques to see sharper phenomena.

This study produces the following findings: (1) At present Central Government still dominates the course of destination development programs in Kabupaten Pulau Morotai, 2) One of the main impacts that occur is the improvement of infrastructure that supports tourism activities in Kabupaten Pulau Morotai. This condition shows that the Morotai Tourism Destinations have potential chance to become the core of tourism industry in North Moluccas Province.
\end{abstract}

Keywords: Morotai, tourism destination, role of public-private sector

\section{Pendahuluan}

Indonesia memiliki dua pembagian jenis kawasan pariwisata prioritas nasional, ke dua jenis tersebut adalah Kawasan Ekonomi Khusus dan Kawasan Strategis Pariwisata Nasional (rapat koordinasi Kementerian Pariwisata “Akselerasi Pembangunan
Kepariwisataan dalam Rangka Pencapaian Target 12 Juta Wisman dan 260 juta Wisnus 2016). Morotai merupakan salah satu dari sepuluh Destinasi Pariwisata Prioritas Nasional dan memiliki jenis Kawasan Ekonomi Khusus. Kondisi pariwisata di 
kawasan ini belumlah berkembang pesat, namun potensi kekayaan alam bawah laut, budaya, dan sejarahnya membuat pemerintah meliriknya sebagai salah satu kawasan yang akan dikembangkan sektor kepariwisataannya secara maksimal. Morotai dinilai memiliki keunggulan geoekonomi dan geostrategis (Peraturan Pemerintah Republik Indonesia Nomor 50 Tahun 2014 Tentang Kawasan Ekonomi Khusus Pariwisata Morotai, 2014). Keunggulan geoekonomi yang dimiliki Morotai adalah letaknya yang berada pada pulau terluar di sisi timur laut indonesia yang berdekatan dengan Jepang dan Taiwan serta berada pada jalur imigrasi ikan tuna yang menunjang industri perikanan di wilayah ini. Keunggulan Geostrategis yang dimiliki morotai adalah adanya kebijakan untuk menghidupkan kembali dan memaksimalkan peran bandar udara Pitu sebgai hub internasional di kawasan timur Indonesia. Pada tahun 2019 Morotai ditargetkan dapat menarik 500.000 wisman dan mendapatkan devisa sebanyak 500 juta USD.

Pihak pemerintah pusat telah merencanakan pembangunan infrastruktur agar dapat mengejar target yang telah ditetapkan. Ada sembilan pokok pembangunan infrastruktur yang disiapkan pemerintah, yaitu 1) Pengembangan pengelolaan sarana air, 2) Pengendalian banjir dan pengamanan pantai Morotai, 3) Pembangunan jalan baru sepanjang $154 \mathrm{Km}$ di kabupaten Morotai, 4) Pemeliharaan, pelebaran, rekonstruksi, dan rehabilitasi jalan, 5) Pengembangan kawasan pemukiman, 6) Subsidi angkutan laut perintis pangkalan ternate, 7) Pembangunan lampu pelabuhan morotai, 8) peningkatan GMDSS SROP Ternate, 9) Pembangunan landasan terbang dan operasional Bandara Pitu.

Tidak hanya pihak pemerintah yang berkontibusi besar dalam memberikan bantuan terkait pengembangan kepariwisataan Morotai sampai hari ini, Pihak swasta atau investor pun sudah masuk di dalam kegiatan pengembangan destinasi wisata Kabupaten Pulau Morotai. PT. Jababeka Morotai yang merupakan anak perusahaan PT. Kawasan Industri Jababeka. Tbk. merupakan pengusul dari Kawasan Ekonomi Khusus (KEK) Morotai dan telah ditetapkan melalui Surat Keputusan Bupati Pulau Morotai No. 538.3/191/PM/2014 Tahun 2014 pada 18 September 2014 sebagai perusahaan pembangun dan pengelola kawasan tersebut. Pada saat ini nilai investasi yang terdapat pada Kawasan Ekonomi Khusus Pariwisata Morotai mencapai nilai 6,8 Triliun Rupiah (http://kek.go.id/kek-di-indonesia/ morotai/). Kondisi ini memperlihatkan secara kasar sudah terlihat pelibatan dari masing-masing sektor baik pemerintah dan swasta.

Penelitian ini merupakan penelitian Deskriptif Kualitatif yang akan menjelaskan secara kualitatif peran masing-masing sektor dan dampaknya terhadap perkembangan destinasi wisata Kabupaten Pulau Morotai. Penjelasan akan diuraikan mulai dari penjabaran terkait laju perkembangan destinasi Morotai sampai saat ini, peran masing-masing stakeholder yang terlibat dalam dan dampaknya terhadap perkembangan destinasi wisata di Kabuptaten Pulau Morotai.

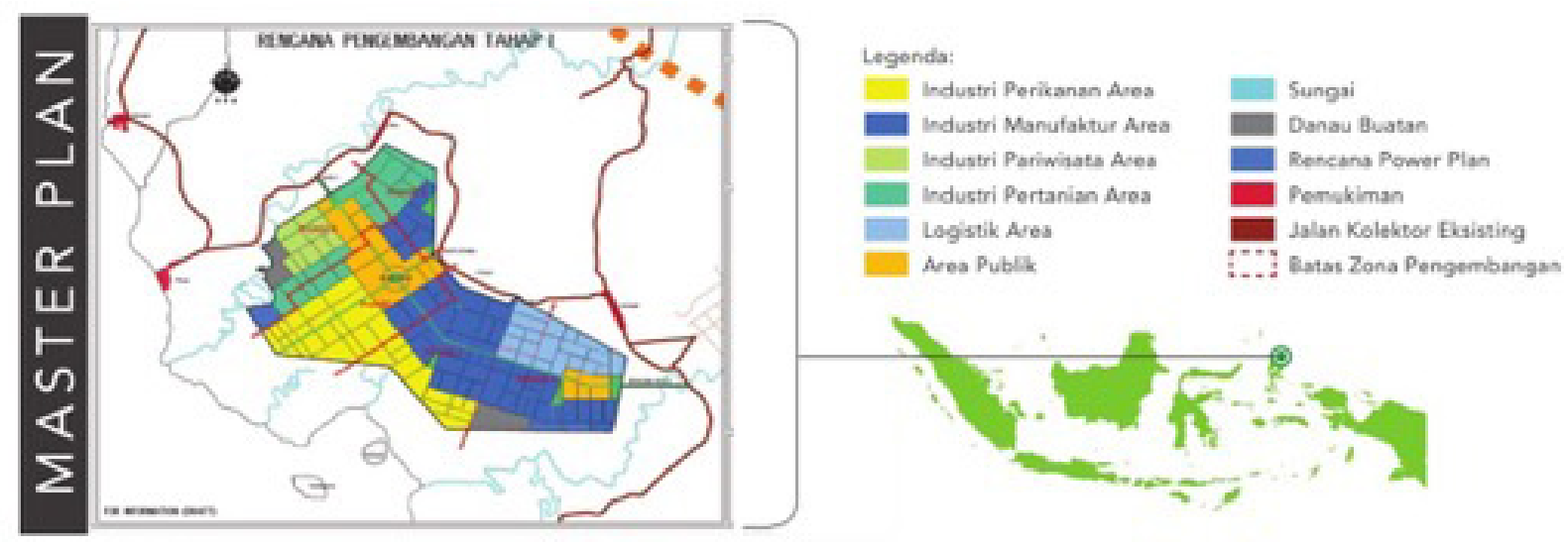

Gambar 4.1. Peta Kawasan Ekonomi Khusus Pariwisata Morotai Sumber: http://kek.go.id/kek-di-indonesia/morotai/ 


\section{Landasan Teori}

Pergeseran paradigma pusat inisiator dan penggerak pembangunan dari Goverment menjadi Governance (State, Private, dan Society) (Derkzen, Franklin, \& Bock, 2008; UNDP, 1997)and Wales particularly, inclusion and equal opportunities for all became key principles guiding the work of the many partnerships that were established at the beginning of this century. A primary objective of this paper is to develop a greater understanding of the politics and processes within 'partnership' as a widely used governance instrument. We argue that rather than dismissing partnerships for their exclusionary mechanisms, they might be considered as distinctive 'arenas of power' where the emphasis on participation and consensus shapes power relations in particular ways. What we demonstrate, using a differentiated topology of power [Allen, J., 2003. Lost Geographies of Power. Blackwell Publishing], is the effect that different modes of power, at different times, can have on social interaction and the process of partnership working. Although inequality in terms of resources existed in our study, we show that effective partnership working was enhanced at times when more reciprocal modes of power were used. We conclude, therefore, that an analysis of power based on resources alone is limited because the use and effect of resources may be \"modified, displaced or disrupted depending upon the relationships that come into playl" [Allen, J., 2003. Lost Geographies of Power. Blackwell Publishing, p. 97]. Hence, there is a need for more research on power struggles and conflicts in partnerships over time. Only then it is possible to see how and when differences in resources affect social interaction and result in different levels of (in yang biasanya dilatarbelakangi keterbatasan modal pemerintah dalam melakukan pembangunan yang optimal di suatu kawasan. Kondisi ini mendorong adanya pelibatan yang kuat sektor swasta untuk dapat mendukung pembangunan dengan kekuatan pada porsinya masing-masing. Banyaknya aktor yang terlibat di dalam pengembangan kegiatan wisata di destinasi wisata Kabupaten Pulau Morotai membuat kompleksnya permasalahan pengorganisasian kegiatan antar sektor. Tiap-tiap aktor memiliki kekuatan dan kelemahan masingmasing sehingga sinergitas antar sektor swasra dan sektor pemerintah dengan karakternya masing- masing akan memberikan win-win solution bagi masalah-masalah yang muncul di kawasan tersebut (Soderberg and Eckerberg in Bjärstig \& Sandström, 2017; Nuryanti \& Hwang, 2002).

Pemerintah merupakan aktor sentral dalam perkembangan suatu destinasi wisata di kebanyakan negara berkembang. Akses yang kuat terhadap kekuasaan dan sebagai penentu kebijakan dalam usaha pengembangan suatu destinasi wisata menjadi modal utama sektor pemerintah berkontribusi dalam kegiatan wisata (Nuryanti \& Hwang, 2002). Sektor swasta dengan keunggulannya pada bidang penyediaan modal secara cepat, mengikuti perkembangan jaman, dan memiliki tenaga-tenaga kerja yang profesional menjadi sektor yang dapat menutupi kekurangan dari sektor pemerintah.

Peran dan fungsi sektor pemerintah dan swasta dalam pelaksanaan konsep kerjasama pemerintah-swasta tergambar dalam tabel 2.1.

Pine (2002) menjelaskan bahwa peran yang dimiliki oleh sektor pemerintah maupun swasta berangkat dari kemampuan dasar yang dimiliki oleh masing-masing sektor. Untuk Sektor pemerintah biasanya memiliki kekuatan akan kuasa terhadap pembuatan undang-undang, kebijakan, serta peraturan yang berpengaruh terhadap kawasan (Shen, Platten, \& Deng, 2006). Namun kelemahan yang ada dari sektor pemerintah biasanya bersifat labil. Jika pada suatu sistem pemerintahan menggunakan skala tahun kepemimpinan tertentu, maka fokus dari kebijakan juga akan mengikuti masa-masa pemilihan yang berjangka pendek.

Jika suatu kebijakan dari pemerintahan sebelumnya dirasa tidak sesuai dengan arah pembangunan pada pemerintahan yang menjabat, maka kebijakan yang sudah berjalan pun dapat diubah sehingga berpengaruh pada pelaksanaan rencana program yang sudah berjalan. Untuk sektor private atau swasta kekuatan yang paling utama adalah sifatnya yang dinamis akan perkembangan pasar, serta kekuatan modal yang dimiliki (Yescombe, 2007). Peran sektor swasta menjadi penting dalam kebutuhan sebagai pemantik kegiatan ekonomi di daerah yang dikembangkannya. Dalam kerjasama pemerintah-swasta kekuatan dan kelemahan dari masing-masing sektor dapat dikombinasikan untuk mencapai tujuan pembangunan yang maksimal.

Kelemahan dari sektor pemerintah yang biasanya bersifat lambat, minim dana, dan jauh 
Tabel 2.1. Peran Pemerintah dan Swasta Dalam Kerjasama Pemerintah-Swasta

\begin{tabular}{|c|c|}
\hline Aktor & Peran \\
\hline \multirow{7}{*}{$\begin{array}{l}\text { Pemerintah } \\
\text { Pusat }\end{array}$} & Pembuatan kebijakan dan penentuan strategi pengembangan kawasan \\
\hline & Pembuatan peraturan terkait perlindungan konsumen \\
\hline & Menjadi inisiator dalam pembentukan forum koordinasi \\
\hline & Keterlibatan (Jika diperlukan) terkait kebijakan fiskal \\
\hline & Menciptakan kenyamanan kondisi untuk sektor swasta dalam berinvestasi \\
\hline & Sebagai agen promosi destinasi ke luar negeri \\
\hline & $\begin{array}{l}\text { Sebagai care taker parabola sektor swasta mengalami } \\
\text { kegagalan dalam upaya pengembangan kawasan }\end{array}$ \\
\hline \multirow{4}{*}{$\begin{array}{l}\text { Pemerintah } \\
\text { Daerah }\end{array}$} & Pembangunan dan perawatan jalan \\
\hline & Pembangunan dan perawatan pelabuhan \\
\hline & Suplai air \\
\hline & Pembangunan telekomunikasi \\
\hline \multirow{5}{*}{ Swasta } & Pembangunan dan penyediaan sarana akomodasi \\
\hline & Pembuatan toko-toko souvenir \\
\hline & Penyedia sarana hiburan (entertainment) \\
\hline & Pendukung sarana transportasi \\
\hline & Pendukung pengembangan atraksi wisata \\
\hline
\end{tabular}

Sumber: Lickorish, Jefferson, Bodlender, \& Jenkins. 1994

dengan kondisi pasar dapat ditutupi dengan kekuatan dari sektor swasta yang dapat masuk pada ranah penyediaan pendanaan dan pengembangan alur bisnis untuk menunjang kegiatan ekonomi di suatu kawasan, serta perencanaan bisnis yang dapat menarget potensi pasar wisatawan yang paling memungkinkan untuk disasar (Bjärstig \& Sandström, 2017). Begitu juga dengan kelemahan dari sektor swasta yang biasanya terbentur pada kewenangan dalam pengembangan kawasan serta akses terhadap perijinan yang terkadang menjadi sulit. Kelemahan ini ditutupi oleh kapasitas dari sektor pemerintah yang memang berwenang sebagai agen pembuat peraturan dan kebijakan serta memperlancar perijinan.

Peran dari masing-masing sektor dan pengimplementasian program pengembangan destinasi wisata menjadi kunci dari suatu destinasi wisata dapat menjadi pusat (core) industri pariwisata. Konsep Pusat (core) dan pinggiran (peripherry) sendiri dikemukanan oleh Papatheodorou (2006) yang menilai suatu daerah akan menjadi pusat industri wisata dalah suatu batasan regional tertentu apabila memiliki keragaman dan kelengkapan atraksi wisata, kemudahan akses terhadap pusat wisatawan, dan kelengkapan amenitas pendukung kegiatan wisata.

\section{Metodologi Penelitian}

Dalam penelitian ini metodologi penelitian yang tepat untuk digunakan adalah metode penelitian Kualitatif. Metode ini dipilih karena sifatnya yang mengedepankan bukti empiris untuk mengeksplorasi suatu fenomena dengan menggunakan data dari berbagai narasumber (Sarosa, 2012). Pengumpulan data menggunakan teknik observasi, wawancara mendalam, dan survey isntitusional. Data primer diambil dengan menggunakan teknik wawancara mendalam dengan lembaga-lembaga yang terlibat dalam pengembangan destinasi wisata Kabupaten Pulau Morotai seperti DN KEK Republik Indonesia, Kementerian Pariwisata Republik Indonesia, Dinas Pariwisata Provinsi Maluku Utara dan Kabupaten Pulau Morotai, Bappeda Provinsi Maluku Utara dan Kabupaten Pulau Morotai, serta PT. Jababeka Morotai. Selain itu observasi lapangan juga dilaksanakan untuk menunjang data-data lapangan 
di Kabupaten Pulau Morotai selama satu bulan (28 Februari 2018 - 28 Maret 2018). Sedangkan data sekunder diambil dari sumber-sember resmi lembaga yang terlibat dan hasil dari survey institusional yang telah dilaksanakan.

Penentuan informan dalam penelitian ini menggunakan sistem purposive sampling dengan tujuan mendapatkan sebanyak-banyaknya informasi dari narasumber yang sudah ditentukan tingkat kepentingannya. Teknik analisis data penelitian ini menggunakan teknik triangulasi data dan analisis deskriptif kualitatif yang ditujukan untuk dapat melihat lebih tajam data-data kualitatif yang sudah terkumpul.

\section{Pembahasan}

\subsection{Peran Sektor Pemerintah dan Sektor Swasta}

Pemerintah yang memiliki andil sebagai penanggung hajat hidup orang banyak, serta lembaga yang bertanggung jawab dan memiliki kekuasaan dalam pembuatan peraturan serta undang-undang yang dapat mendukung pembangunan sektor pariwisata di daerahnya. Secara umum pemerintah memiliki tiga peran utama, yaitu sebagai pembuat rencana kebijakan dan strategi pembangunan, pembentukan lembaga pariwisata dan struktur organisasinya, serta berperan sebagai enterprener atau inisiator dalam pengembangan awal suatu destinasi wisata (Nuryanti \& Hwang, 2002).

Di dalam konteks pemerintahan di Indonesia, terdapat dua tingkatan sektor pemerintah yang memiliki kuasa di dalam pengelolaan wilayah. Kedua tingkatan tersebut adalah pemerintah pusat seperti kementerian-kementerian dan dewan nasional serta pemerintah daerah dalam lingkup provinsi dan kabupaten kota dengan masingmasing kedinasannya. Kedua level pemerintahan ini akan saling bersinergi di dalam pembangunan sektor kepariwisataan yang memiliki berdaya saing nasional maupun internasional. Kabupaten Pulau Morotai sendiri memiliki dua status nasional yang memungkinkan pelibatan pemerintah dari tingkat pusat hingga daerah dalam pengembangan kawasannya. Kedua status tersebut adalah Kabupaten Pulau Morotai yang memiliki Kawasan Ekonomi Khusus serta Kabupaten Pulau Morotai sebagai satu dari sepuluh destinasi pariwisata prioritas nasional yang ditetapkan oleh Kementerian Pariwisata Indonesia.

\subsubsection{Peran Sektor Pemerintah}

Pemerintah Pusat memiliki beberapa peran utama dalam pengembangan sebuah destinasi antara lain sebagai pembuat kebijakan dan penentuan strategi pengembangan kawasan, menjadi koordinator dalam pembentukan forum koordinasi, menciptakan kenyamanan kondisi untuk sektor swasta dalam berinvestasi, sebagai agen promosi destinasi wisata ke luar negeri, dan sebagai care taker sektor swasta apabila mengalami kegagalan pelaksanaan pengembangan kawasan (Lickorish dkk., 1994).

a. Pemerintah sebagai pembuat kebijakan dan penentuan strategi pengembangan kawasan

Dalam skala nasional peran pemerintah sebagai pembuat kebijakan menjadi sangat sentral, hal ini terkait dengan sinergitas pengembangan tiap kawasan yang seharusnya berjalan secara berdampingan dalam lingkup perkembangan nasional. Posisi sebuah kebijakan dan rencana pengembangan kawasan akan menjadi sangat penting karena akan menjadi acuan baik oleh sektor pemerintah maupun sektor swasta dalam melakukan kegiatan pengembangan di dalam suatu kawasan.

Sebagai badan otoritas tertinggi, pemerintah republik indonesia telah membuat beberapa kebijakan strategis yang menjadi dasar bagi pengembangan destinasi wisata di Kabupaten Pulau Morotai.

Tabel 4.1. Kebijakan-Kebijakan Strategis dalam Pengembangan Destinasi

Pariwisata Kabupaten Pulau Morotai

\begin{tabular}{|c|c|}
\hline Kebijakan & Tahun \\
\hline $\begin{array}{c}\text { Rencana Induk Pembangunan } \\
\text { Pariwisata Nasional }\end{array}$ & 2010 \\
\hline $\begin{array}{c}\text { Masterplan Percepatan dan Perluasan } \\
\text { Pembangunan Ekonomi Indonesia (MP3EI) }\end{array}$ & 2011 \\
\hline $\begin{array}{c}\text { Penetapan Kawasan Ekonomi } \\
\text { Khusus Morotai }\end{array}$ & 2014 \\
\hline $\begin{array}{c}\text { Penetapan Morotai Sebagai 10 } \\
\text { Destinasi Pariwisata Nasional }\end{array}$ & 2016 \\
\hline
\end{tabular}

Sumber: Hasil Analisis Peneliti, 2018 
b. Pemerintah sebagai koordinator dalam pembentukan forum koordinasi

Koordinasi menjadi hal yang penting di dalam pelaksanaan program-program lintas lembaga (Dinica, 2009). Dalam hal ini pemerintah memiliki peran besar dalam kegiatan pembentukan forum koordinasi dan juga dapat bertindak menjadi koordinator dari program-program pengembangan wilayah di daerah yang menjadi otoritasnya.

Seperti halnya yang terjadi di dalam pelaksanaan pengembangan destinasi wisata di Kabupaten Pulau Morotai keterlibatan lembaga lintas tingkatan cukuplah tinggi. Banyaknya intervensi pengembangan wilayah dari lembaga yang berbeda membutuhkan koordinasi yang kuat untuk menjaga berjalannya program secara baik. Peran pemerintah sebagai agen pembentuk forum koordinasi dan koordinator dalam beberapa program pembangunan pariwisata di Morotai tergambar pada tabel yang ada di bawah ini

Tabel 4.2. Peran Pemerintah Sebagai

Agen Pembentuk Forum Koordinasi dan Sebagai Koordinator

\begin{tabular}{|c|c|}
\hline Kebijakan & Tahun \\
\hline $\begin{array}{c}\text { Pembentukan Dewan Kawasan dan } \\
\text { Administrator KEK Morotai }\end{array}$ & 2014 \\
\hline $\begin{array}{c}\text { Pembentukan UPTD Kawasan } \\
\text { Wisata Pulau Dodola }\end{array}$ & 2014 \\
\hline $\begin{array}{c}\text { Penunjukan PIC destinasi pariwisata } \\
\text { prioritas untuk Kabupaten Pulau Morotai }\end{array}$ & 2017 \\
\hline $\begin{array}{c}\text { Pembentukan tim percepatan } \\
\text { pembangunan KEK Morotai }\end{array}$ & 2018 \\
\hline
\end{tabular}

Sumber: Hasil Analisis Peneliti, 2018

c. Pemerintah sebagai penanggung jawab kenyamanan sektor swasta dalam berinvestasi

Salah satu parameter dari perkembangan kegiatan ekonomi di suatu daerah adalah banyaknya investor yang masuk untuk berinvestasi guna menunjang kegiatan wisata yang ada. Investasi dari sektor swasta akan menjadi pemantik bagi perekonomian suatu destinasi wisata seperti bertambahnya lapangan usaha yang dapat menyerap tenaga kerja dari masyarakat lokal dan dengan sendirinya akan memperbaiki kondisi perekonomian di kawasan tersebut.
Faktor penting yang akan diperhatikan oleh investor adalah adanya jaminan keamanan bagi mereka jika ingin berinvestasi di suatu destinasi wisata. Pemerintah memiliki peranan utama sebagai salah satu sektor yang paling bertanggung jawab akan keamanan dan kenyamanan para investor dalam berinvestasi (Lickorish dkk., 1994).

Sebuah kebijakan spesifik telah dilakukan oleh pemerintah pusat melalui Dewan Nasional Kawasan Ekonomi Khusus guna mendukung kenyamanan dan keamanan investor dalam berinvestasi di Indonesia, secara khusus juga dilaksanakan di Kabupaten Pulau Morotai. Kebijakan ini tertuang di dalam Peraturan Pemerintah Nomor 96 Tahun 2015 Tentang Fasilitas dan Kemudahan Investasi di Kawasan Ekonomi Khusus. Secara khusus untuk investasi di bidang pariwisata pihak swasta akan mendapatkan kemudahan dalam (1) Pengurangan Pajak Penghasilan dalam bentuk Tax Holiday atau Tax Allowance, (2) Paham Pertambahan Nilai dan Pajak Penjualan atas Barang Mewah, (3) Kepabeanan dan Cukai, (4) Kepemilikan Properti Asing, (5) Kemudahan keimigrasian, (6) Kemudahan izin investasi tiga jam.

d. Pemerintah sebagai agen promosi destinasi wisata internasional

Salah satu kekuatan strategis yang dimiliki oleh sektor pemerintah dan dapat dimanfaatkan dalam pengembangan kawasan adalah kekuasaan dan jaringan kerjasama dengan negara lain. Jaringan ini pada nantinya dapat dimanfaatkan sebagai sarana memperkenalkan destinasi wisata sebagai magnet bagi wisatawan asing untuk berkunjung.

Pariwisata sendiri dapat menjadi salah satu sektor penyumbang devisa negara dalam jumlah besar. Devisa ini berasal dari pendapatan yang diperoleh melalui pengeluaran wisatawan asing di tiap-tiap destinasi wisata. Hal ini membuat pemerintah dengan gencar melakukan kegiatan promosi ke luar negeri yang pada akhirnya diharapkan dapat datang berkunjung ke destinasi-destinasi wisata yang ada di Indonesia dan membelanjakan uangnya di sana. Berikut merupakan beberapa program kegiatan promosi yang diinisiasi ataupun dibantu oleh pemerintah dalam upaya mengenalkan destinasi wisata kabupaten Pulau Morotai kepada negara lain. 
Tabel 4.3. Program Kegiatan Promosi Destinasi Pariwisata Morotai di Luar Negeri

\begin{tabular}{|c|c|}
\hline Kebijakan & Tahun \\
\hline Promosi di ITB Berlin & 2018 \\
\hline Promosi di ADEX Singapura & 2018 \\
\hline $\begin{array}{c}\text { Promosi di Marine Diving } \\
\text { Fair (MDF) Jepang }\end{array}$ & 2018 \\
\hline
\end{tabular}

Sumber: Hasil Analisis Peneliti, 2018

e. Pemerintah sebagai care taker sektor swasta apabila mengalami kegagalan pengembangan

Pemerintah dianggap sebagai salah satu sektor yang bertanggung jawab dalam perkembangan suatu kawasan yang berada di bawah otoritas kekuasaannya. Sektor pemerintah diharapkan dapat menjadi care taker atau lembaga yang bertanggung jawab untuk mengambil alih dan memiliki rencana cadangan apabila program-program yang dilaksanakan oleh sektor swasta gagal atau tidak berjalan.

Sampai saat ini rata-rata pelaksanaan program-program strategis dalam kegiatan pembangunan sektor pariwisata di Kabupaten Pulau Morotai masihlah berada di tahap pembangunan serta masih berada dalam proses untuk ditentukan apakah program tersebut berjalan dengan semestinya ataukah gagal. Kondisinya sampai saat ini pemerintah pusat maupun daerah belum memiliki rencana cadangan secara tertulis yang menanggulangi resiko kegagalan dari kegiatan pengembangan yang dilakukan oleh sektor swasta.

Dalam kasus pengembangan Kawasan Ekonomi Khusus Morotai pada tahun 2017, Dewan Nasional Kawasan Ekonomi Khusus telah mengevaluasi bahwa KEK Morotai yang mulanya ditargetkan dapat beroperasi pada tahun 2017 belum dapat beroperasi. Hal ini dikarenakan belum terpenuhinya syarat-syarat minimal suatu Kawasan Ekonomi Khusus untuk dapat beroperasi.

\subsubsection{Peran Sektor Swasta}

Sebelumnya sudah dijelaskan tentang peran dari sektor publik atau pemerintah yang secara umum lebih bersifat jangka panjang dan cenderung bertumpu pada kekuatan akses terkait kekuasaan dalam suatu wilayah maka sektor lain yang memiliki peran utama dalam kegiatan kerjasama pemerintah- swasta adalah sektor swasta (private). Sektor swasta lebih cenderung bersifat cepat dalam menyesuaikan perkembangan jaman, memiliki keunggulan modal, serta lebih fleksibel dalam melakukan bisnis. Hal tersebut muncul salah satunya karena sifat dasar sektor swasta sebagai sektor yang lebih berorientasi pada keuntungan atau profit (Nuryanti \& Hwang, 2002). Kekuatan serta keunggulan masing-masing sektor diharapkan dapat saling mengisi secara sinergis untuk pembangunan suatu kawasan.

Saat ini jumlah aktor sektor swasta yang terlibat dalam pengembangan destinasi di Kabupaten Pulau Morotai masih sedikit. Dari Hasil observasi lapangan ditemukan hanya terdapat tiga lembaga dari sektor swasta yan terlibat dalam pengembangan destinasi wisata di Kabupaten Pulau Morotai secara mandiri. Lembaga yang pertama adalah PT Jababeka Morotai yang bekerjasama dengan pemerintah dari tingkat pusat, regional, dan lokal dalam pengembangan Kawasan Ekonomi Khusus Morotai, sedangkan lembaga yang ke dua adalah PT HM Sampoerna (Tbk) yang bekerjasama dengan pemerintah Kabupaten Pulau Morotai dan Yayasan Inspirasi Anak Bangsa dalam program pembangunan Desa Kolorai sebagai atraksi wisata baru dan lembaga yang ke tiga adalah PT Telkomsel yang berperan dalam menyediakan sarana telekomunikasi di Kabupaten Pulau Morotai.

Lickorish dkk (1994) mengatakan bahwa sektor swasta memiliki lima peran utama dalam pengembangan sebuah destinasi wisata. Ke lima peran tersebut adalah sektor swasta sebagai agen pembangunan dan penyediaan sarana akomodasi, pembuat toko-toko souvenir atau pusat perbelanjaan, penyedia sarana hiburan, pendukung sarana transportasi, dan yang terakhir berperan sebagai pendukung pengembangan atraksi wisata. Dalam kasus pengembangan destinasi wisata di Kabupaten Pulau Morotai sektor swasta yang berperan dalam program kerjasama pemerintah-swasta saat ini hanya mengambil bagian dalam dua peran dari lima peran sektor swasta yang dipaparkan oleh lickorish dkk. Ke dua peran tersebut adalah sebagai pembangun dan penyedia sarana akomodasi serta sebagai pendukung pengembangan atraksi wisata.

a. Sektor swasta sebagai pembangun dan penyedia sarana akomodasi

Pada tahun 2012 berbarengan dengan diadakannya 
Sail Morotai oleh pemerintah pusat Republik Indonesia. PT Jababeka Morotai memulai masa investasinya di wilayah Kabupaten Pulau Morotai. Pada tahun itu PT Jababeka Morotai membangun sarana akomodasi yang diberi nama D'aloha Resort di kawasan tanjung dehegila berupa bungalow yang berada persis di bibir pantai.

Sampai saat ini D'aloha Resort masih beroperasi dan menjadi salah satu sarana akomodasi yang menjadi pilihan utama bagi lembaga-lembaga pemerintah maupun swasta untuk penginapan sekaligus sarana penunjang kegiatan M.I.C.E di Kabupaten Pulau Morotai.
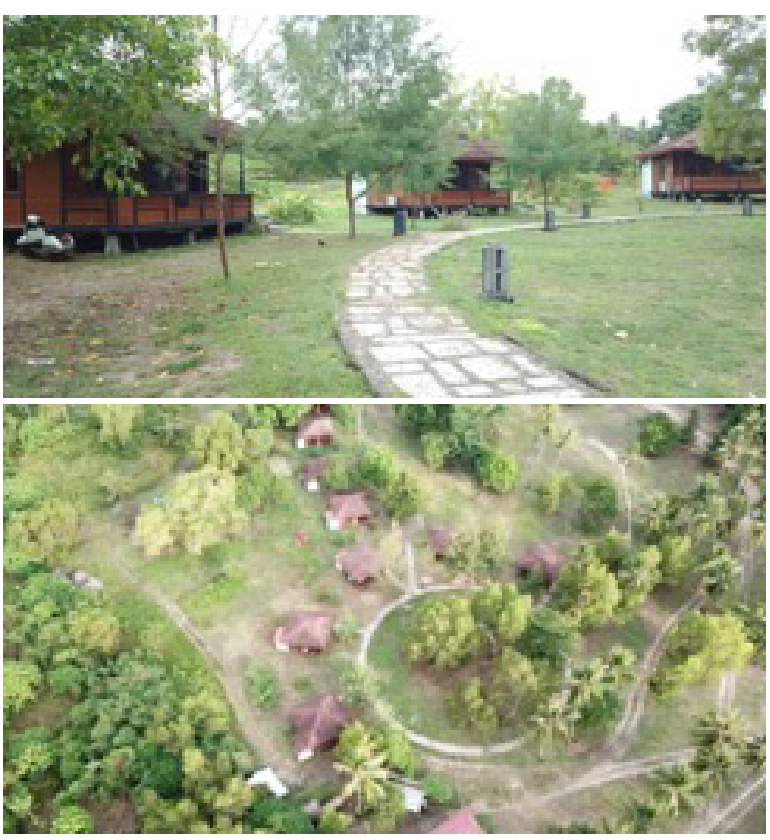

Gambar 4.2. D'aloha Resort Jababeka

Sumber: Hasil Survey Peneliti dan Pradikta Dwi Antoni, 2018

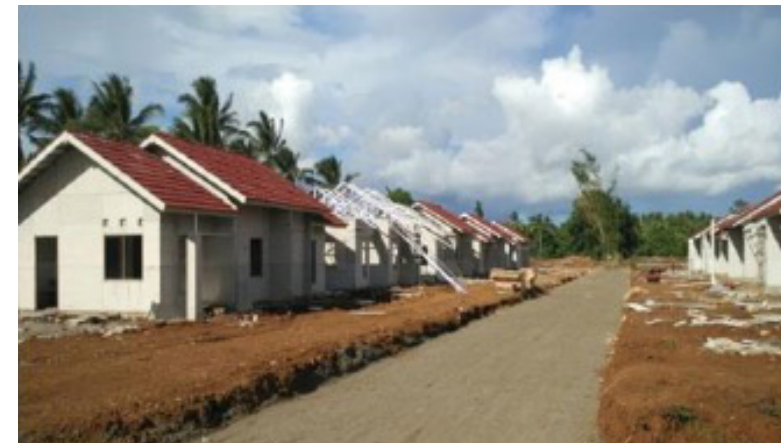

Gambar 4.3. Homestay di KEK Morotai Sumber: Hasil Survey Peneliti, 2018
Pada tahun 2018 sedang terdapat pekerjaan pembangunan pusat akomodasi di daerah Desa Dehegila. Sarana akomodasi ini berupa 41 unit homestay yang dibangun di atas lahan Kawasan Ekonomi Khusus Morotai. Keberadaan homestay ini diharapkan dapat menjadi pemenuhan kebutuhan akan kurangnya sarana akomodasi yang terdapat di destinasi wisata Kabupaten Pulau Morotai khususnya pada kawasan di bagian barat Pulau Morotai.

b. Sektor swasta sebagai pendukung pengembangan atraksi wisata

Selain sebagai aktor yang membangun dan menyediakan layanan akomodasi sektor swasta di Kabupaten Pulau Morotai juga memberikan peningkatan atraksi wisata melalui beberapa program yang dilakukan oleh masing-masing unit usahanya.

Lokasi D'aloha Resort yang dikelola oleh PT Jababeka Morotai berada di Tanjung Dehegila, dimana lokasi tersebut berada di dekat pusat kegiatan ekonomi dan pemerintahan Kabupaten Pulau Morotai yaitu Kota Daruba. Letak Resort yang juga berada pada kawasan pantai membuat PT Jababeka Morotai mempunyai kesempatan besar dalam merespon kegiatan-kegiatan wisata yang ada di sekitarnya. Terlebih lagi D'aloha Resort terletak persis berseberangan dengan lokasi gugusan pulaupulau kecil yang menjadi atraksi wisata andalan dari Kabupaten Pulau Morotai.

PT Jababeka Morotai melalui D'aloha Resort juga mendukung kegiatan wisata bawah laut di Kabupaten Pulau Morotai. Pihak PT Jababeka Morotai bekerja sama dengan klub selam lokal (Dive Morotai) dalam penyediaan kegiatan ini. Dibe Morotai merupakan klub selam lokal yang beranggotakan pemuda-pemuda asli dari Kabupaten Pulau Morotai yang memiliki kecintaan terhadap dunia penyelaman. Sebelumnya klub ini memiliki home base di salah satu rumah anggotanya di Kota Daruba, namun pada akhirnya klub selam ini diajak bekerjasama dengan PT Jababeka Morotai dengan memberikan satu bungalow untuk dijadikan kantor operasional kegiatannya.

Kerjasama yang terbentuk adalah kerjasama yang saling menguntungkan bagi ke dua belah pihak, di satu sisi klub selam Dive Morotai dapat memiliki homebase yang lebih representatif untuk 
melaksanakan kegiatannya dan sebagai tempat penyimpanan peralatan-peralatan selamnya. Kemudian untuk PT Jababeka Morotai, khususnya D'aloha Resort mendapat keuntungan kemudahan akses bagi tamunya yang ingin melakukan kegiatan penyelaman di Kabupaten Pulau Morotai. Hal ini juga yang membuat D'aloha resort menjadi salah satu pilihan utama bagi para tamu yang memiliki tujuan utama menikmati kegiatan penyelaman di Kabupaten Pulau Morotai yang terkenal akan wreck atau peninggalan sejarah perang dunia II yang tenggelam di dasar laut, keindahan terumbu karang, dan spot penyelaman hiu di pulau Mitita.

\section{Gambar 4.4. Spot Selam Shark Point dan Terumbu Karang di Morotai}
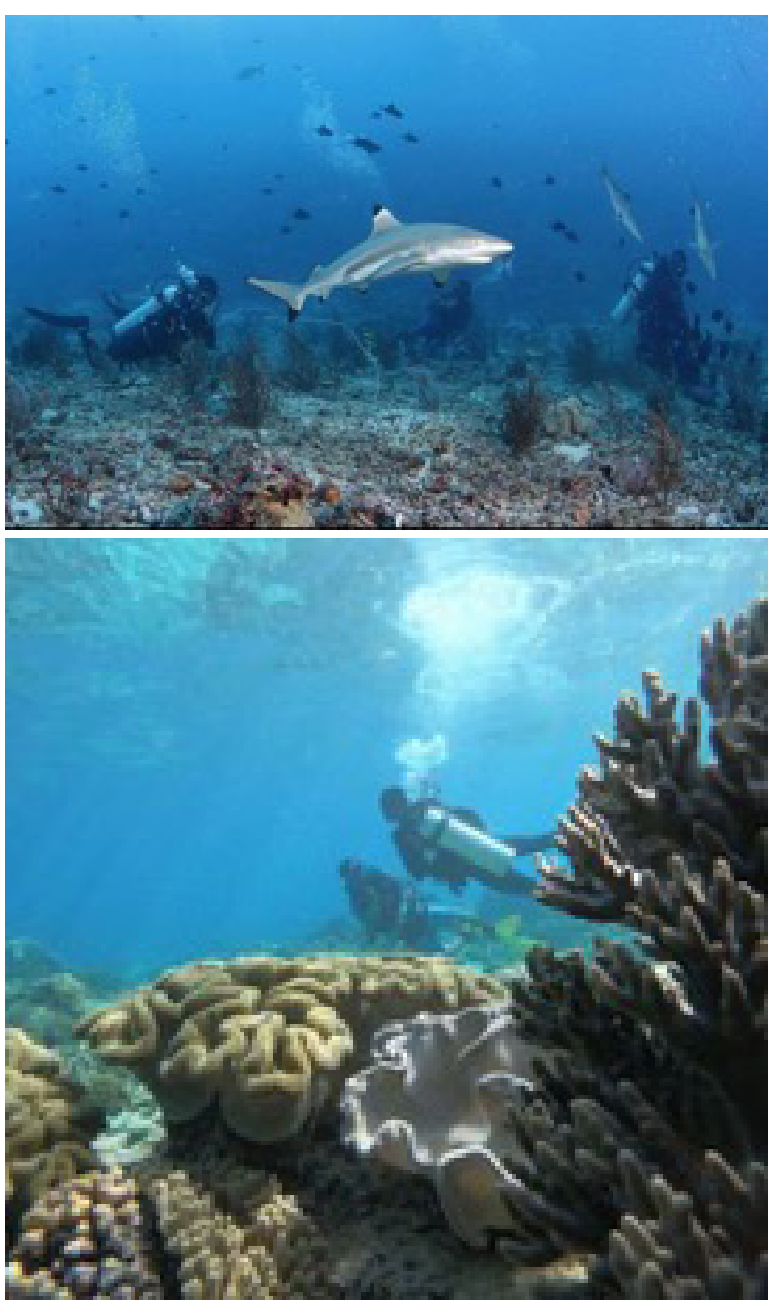

Sumber: Arsip Dive Morotai, 2018

Bentuk kerajasama lain yang berhubungan dengan peningkatan atraksi wisata yang ada di Kabupaten Pulau Morotai adalah kerjasama yang dilakukan oleh PT HM Sampoerna dengan pemerintah Kabupaten Pulau Morotai. Lewat program Corporate Social Resposibility CSR PT HM Sampoerna menggandeng Yayasan Inspirasi Anak Bangsa dan Pemkab Kabupaten Pulau Morotai untuk menjadikan Desa Kolorai sebagai Desa Pelangi.

Desa Kolorai merupakan salah satu desa pulau yang berada dalam satu gugusan kepulauan kecil di Kabupaten Morotai. Lokasi strategis Desa Kolorai yang berada di Pulau Kolorai, yaitu pulau yang diapit oleh pulau Dodola besar dan kecil dengan pulau Kokoya menjadikan pulau ini memiliki potensi besar untuk dapat dikembangkan sektor pariwisatanya. Program Desa Pelangi merupakan tipe program pembuatan atraksi yang sama dengan desa pelangi yang ada di Kota Malang, simana keseluruhan desa akan dicat tembok bagian luar dan atapnya dengan menggunakan cat warna warni. Salah satu tujuan utama pengadaan program ini adalah agar Desa Kolorai memiliki identitas kuat untuk dapat menarik wisatawan berkunjung ke daerahnya.

\section{Gambar 4.5. Desa Pelangi Kolorai}
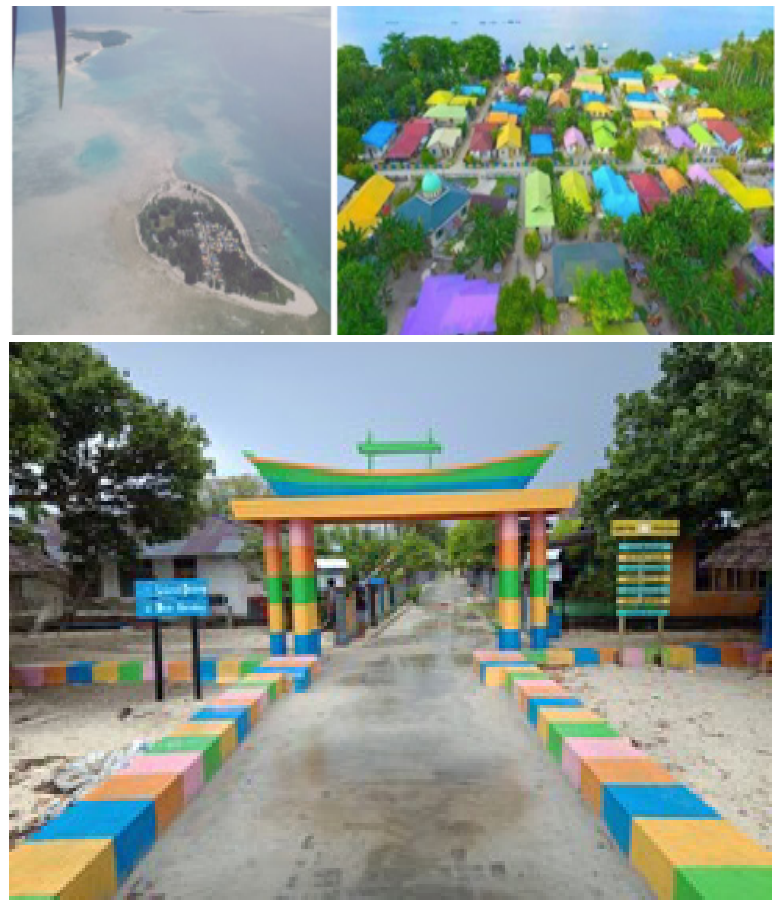

Sumber: Arsip Ketua Dive Morotai Sarif Sengi dan survey peneliti, 2018 


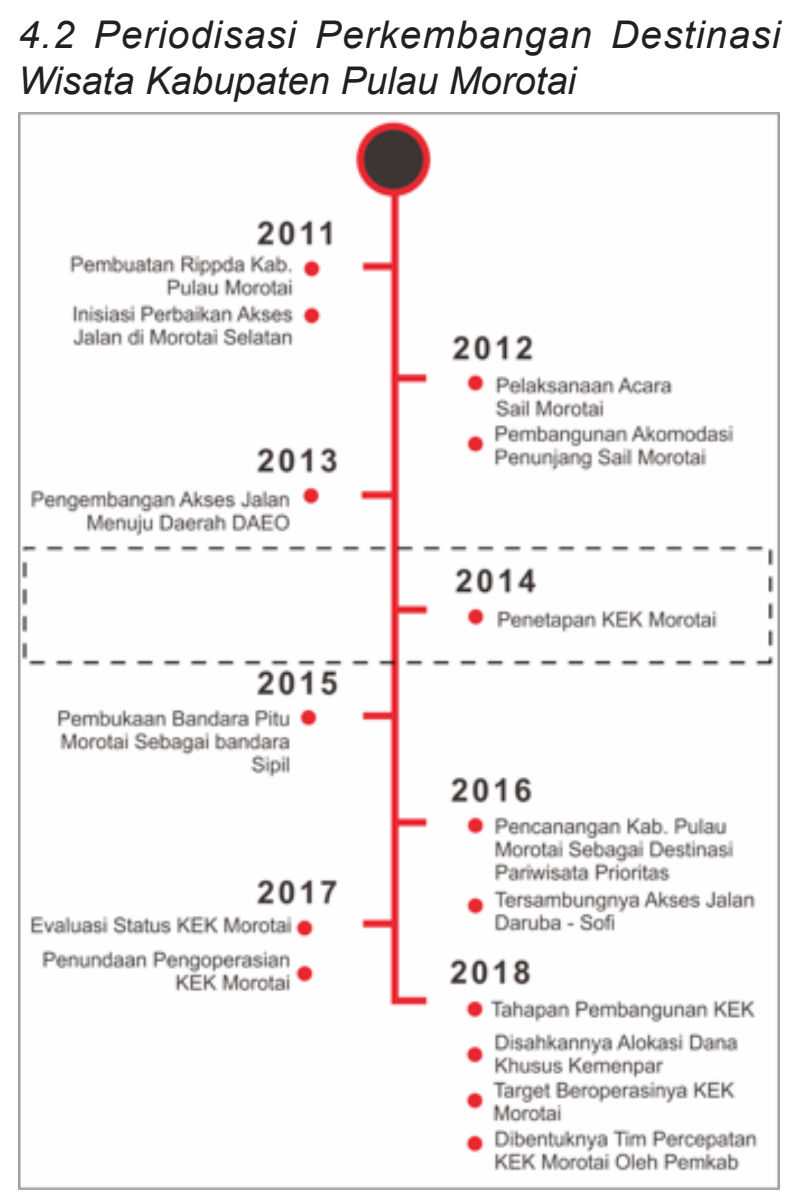

Gambar 4.6. Timeline Perkembangan
Destinasi Kabupaten Pulau Morotai
Sumber: Hasil Analisis Peneliti, 2018

Gambar di atas menunjukan tahun-tahun dalam periode perkembangan destinasi di Kabupaten Pulau Morotai. Perkembangan destinasi dimulai sejak tahun 2011 dan berlangsung hingga saat ini. Awal perkembangan ditandai dengan beberapa program yang berlangsung di wilayah Kabupaten Pulau Morotai seperti dibuatnya Rippda (Rencana Induk Perkembangan Pariwisata Daerah) Kabupaten Pulau Morotai sebagai respon dari posisi strastegis Kabupaten Pulau Morotai sebagai Kawasan Strategis Pariwisata Nasional (Peraturan Pemerintah Republik Indonesia No 50 Tahun 2011). Tahun ini juga menjadi tahun dimulainya persiapan fisik untuk menyambut acara Sail Morotai yang di adakan oleh pemerintah pusat. Tahun ini menjadi tahun awal bagi Kabupaten Pulau Morotai yang mendapat sorotan nasional dalam bidang kepariwisataan sampai pada saat dilaksanakannya Sail Morotai di tahun 2012.
Periode perkembangan yang ke dua adalah pada tahun 2014. Setelah berakhirnya Sail Morotai dan belum ada perkembangan signifikan di destinasi wisata Kabupaten Pulau Morotai, pada tahun ini salah satu wilayah di Kabupaten Pulau Morotai ditetapkan sebagai Kawasan Ekonomi Khusus (KEK) dengan berfokus pada industri perikanan, pariwisata, dan logistik (Keputusan Bupati Pulau Morotai No. 538.3/191/PM/2014, 2014). Status nasional sebagai salah satu Kawasan Ekonomi Khusus menjadi penting dalam pengembangan destinasi wisata di Kabupaten Pulau Morotai. Status ini banyak menjadi pemantik bagi program-program lain yang memiliki peran dalam pengembangan destinasi.

Periode selanjutnya adalah pada tahun 2016. Sebagai respon dari disahkannya KEK Morotai, Kementerian Pariwisata Republik Indonesia menetapkan KEK Morotai sebagi salah satu dari sepuluh destinasi parwisata prioritas di Indonesia (Peraturan Presiden Republik Indonesia Nomor 58 Tahun 2017). Hal ini sama kondisinya seperti Kawasan Ekonomi Khusus di daerah lain yang berfokus pada industri pariwisata dan kesemua kawasan tersebut dijadikan pemerintah sebagai bagian dari sepuluh destinasi pariwisata prioritas di Indonesia seperti KEK Tanjung Lesung, KEK Mandalika, dan KEK Tanjung Kelayang.

Secara garis besar terjadi perubahan pola landasan perkembangan destinasi pada saat sebelum dengan setelah tahun pencanangan KEK Morotai. Pola yang terbentuk pada periode sebelum pencanangan KEK Morotai adalah pemetaan potensi atraksi wisata yang direspon dengan pengembangan aksesibilitas yang menghubungkan pusat kota dengan lokasi-lokasi atraksi wisata unggulan pada bagian selatan Pulau Morotai. Setelah itu baru direspon dengan pembangunan amenitas di simpul-simpul kegiatan wisata dan pusat kota. Sedangkan pola yang terbentuk setelah kebijakan dicanangkannya KEK Morotai adalah perkembangan destinasi yang berawal dari program pencanangan KEK Morotai yang berfokus pada pembangunan amenitas, lalu direspon salah satunya dengan pengembangan jalan lingkar Morotai dan pembangunan bandara sipil, sehingga bermunculan lokasi-lokasi atraksi wisata baru di bagian timur dan utara Pulau Morotai yang mulai dikunjungi wisatawan pasca pembuatan jalan lingkar Morotai. 
Walaupun pembangunan fisik amenitas di lokasi KEK Morotai sendiri baru secara masif terlaksana di tahun 2018, yaitu empat tahun setelah pencanangan program. Lihat gambar 4.7.

\subsection{Ketimpangan Peran Antar Sektor dalam Pelaksanaan Program Pengembangan Destinasi}

Butler (1980) menyebutkan bahwa dalam siklus hidup destinasi wisata tahap pembangunan atau tahap development hadir saat adanya inisiasi dari sektor pemerintah untuk memberikan bantuan terkait pengelolaan kawasan wisata ataupun dalam pembangunan infrastruktur dasar yang menunjang kegiatan wisata. Hal senada juga disampaikan oleh Nuryanti (2002) tentang pentahapan pelaksanaan konsep pemerintah-swasta dalam negara berkembang akan diinisiasi oleh pemerintah sebagai pemantik dari berkembangnya kegiatan wisata di daerahnya yang dalam tahap-tahap selanjutnya akan digantikan perannya oleh sektor swasta. Lihat tabel 4.4.

Jika dikaitkan dengan temuan yang ada di Kabupaten Pulau Morotai seperti yang ada pada tabel di atas terlihat pola yang sama. Yaitu dominasi sektor pemerintah pusat dalam melaksanaan program-program pembangunan guna mendukung berkembangnya sektor industri pariwisata di Kabupaten Pulau Morotai. Hal ini terlihat dari banyaknya program yang dilaksanakan oleh pemerintah sejak tahun 2012 dengan total 18 program serta lima program dilaksanakan bersama dengan pihak swasta. Hal ini berbanding sangat jauh dengan jumlah program yang dilaksanakan oleh pihak swasta secara tunggal, yaitu hanya terdapat dua program.

Kondisi ini menggambarkan tahapan awal pembangunan kawasan dengan pola kerjasama pemerintah-swasta yang dikemukakan oleh Nuryanti (2002). Pemerintah pusat memiliki intervensi yang besar terhadap pembangunan destinasi Kabupaten Pulau Morotai dan sebagian besarnya berfokus pada pembangunan kebutuhan dasar guna menjadi pemantik bagi pergerakan industri pariwisata di Kabupaten Pulau Morotai seperti pembangunan bandara, pembangunan jalan lingkar morotai, penguatan jaringan internet, dan pengalokasian dana bantuan untuk pembangunan infrastruktur fisik di KSPN Morotai.

Untuk program-program yang dilaksanakan oleh sektor pemerintah di Kabupaten Pulau Morotai, besarnya dominasi pemerintah hanya telihat pada struktur pemerintahan pusat. Hal ini memunculkan ketimpangan porsi keterlibatan

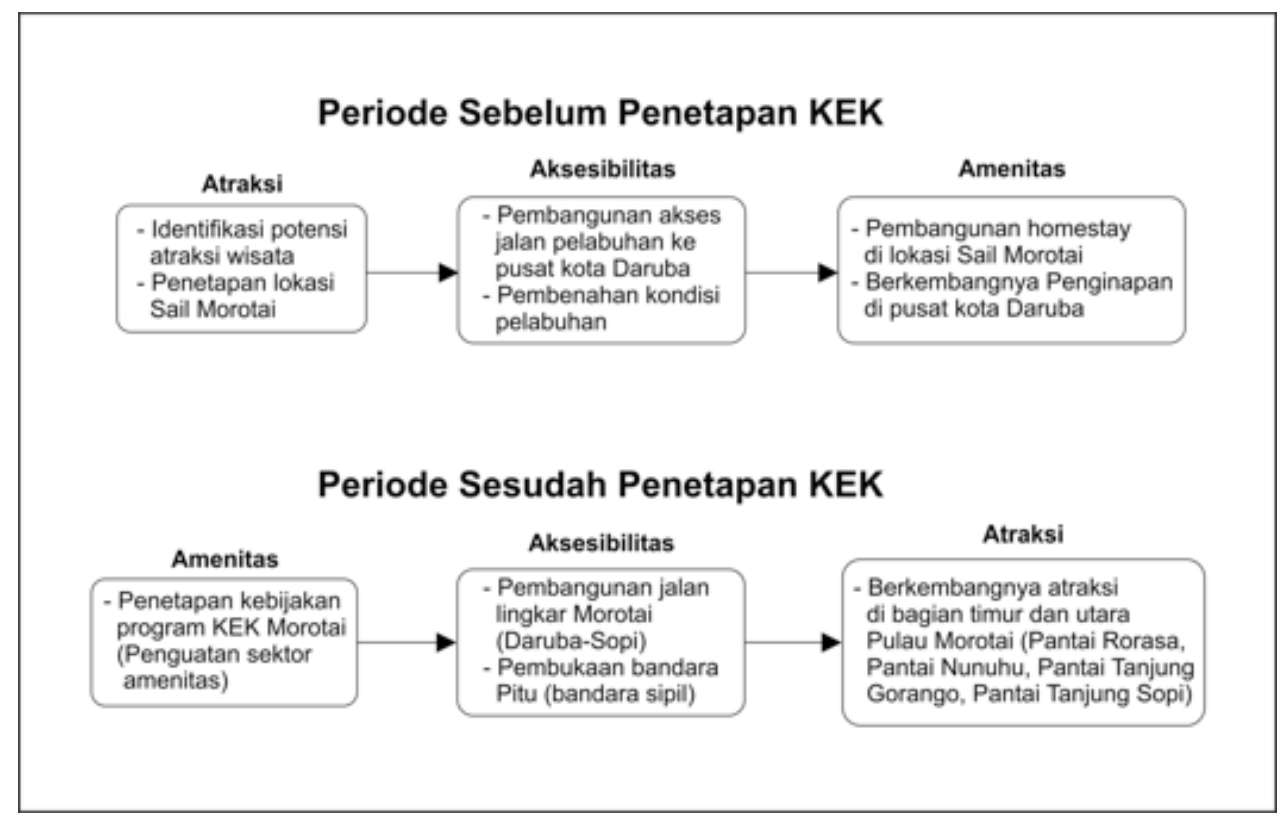

Gambar 4.7. Alur Perkembangan Destinasi Pariwisata Kabupaten Pulau Morotai Sumber: Hasil Analisis Peneliti, 2018 
Tabel 4.4. Program-program dalam pengembangan destinasi wisata di Kabupaten Pulau Morotai

\begin{tabular}{|c|c|c|c|}
\hline No & Program & Tahun Pelaksanaan Program & Pelaksana \\
\hline 1 & Sail morotai & 2012 & Pemerintah pusat \\
\hline 2 & Pembangunan Jalan Trans Morotai & 2011-2017 & $\begin{array}{l}\text { PPK Pelaksana jalan } \\
\text { Pulau Morotai }\end{array}$ \\
\hline 3 & $\begin{array}{l}\text { Pembuatan Museum Perang } \\
\text { dunia II dan Museum Trikora }\end{array}$ & 2014 & Kemendikbud \\
\hline 4 & $\begin{array}{c}\text { Penetapan jalan Trans Morotai } \\
\text { sebagai jalan nasional }\end{array}$ & 2014 & Kementerian PU \\
\hline 5 & Pengeoperasian Bandara Pitu Morotai & 2015 & Kemenhub \\
\hline 6 & $\begin{array}{l}\text { Pengerasan dan penambahan } \\
\text { gedung Bandara Pitu Morotai }\end{array}$ & $2017-2018$ & Kemenhub \\
\hline 7 & $\begin{array}{l}\text { Pembenahan Pelabuhan Daruba } \\
\text { (Pembuatan dermaga apung) }\end{array}$ & 2015 & Kemenhub \\
\hline 8 & $\begin{array}{l}\text { Pengadaan sarana wahana } \\
\text { air Pulau Dodola }\end{array}$ & 2016 & Kemenpar \\
\hline 9 & $\begin{array}{l}\text { Pembuatan akses jalan sipil } \\
\text { menuju bandara Pitu Morotai }\end{array}$ & 2017 & Kemenhub \\
\hline 10 & Pembuatan MIAMARI & 2018 & KKP \\
\hline 11 & Pengadaan Fiber Optik (Palapa Ring) & 2018 & BPPTI \\
\hline 12 & penetapan status KEK & 2014 & DN KEK \\
\hline 13 & $\begin{array}{c}\text { Penetapan status Destinasi Pariwisata } \\
\text { prioritas (Wonderfull Morotai) }\end{array}$ & 2016 & Kemenpar \\
\hline 14 & $\begin{array}{l}\text { Penunjukan PIC khusus } \\
\text { Destinasi Wisata Morotai }\end{array}$ & 2017 & Kemenpar \\
\hline 15 & $\begin{array}{l}\text { Pelatihan operator wahana } \\
\text { air di Pulau Dodola }\end{array}$ & 2016 & Dinpar Kab. Pulau Morotai \\
\hline 16 & $\begin{array}{c}\text { Pembuatan Plang nama dan } \\
\text { Gazebo di lokasi-lokasi yang } \\
\text { terdapat atraksi wisata }\end{array}$ & 2017 & Dinpar Kab. Pulau Morotai \\
\hline 17 & $\begin{array}{c}\text { Pembuatan Ripda Kabupaten } \\
\text { Pulau Morotai } \\
\end{array}$ & 2011 & Dinpar Kab. Pulau Morotai \\
\hline 18 & Pembentukan UPTD Pulau Dodola & 2014 & Dinpar Kab. Pulau Morotai \\
\hline 19 & $\begin{array}{c}\text { Pembangunan Homestay } \\
\text { di kawasan KEK }\end{array}$ & 2018 & PT Jababeka Morotai \\
\hline 20 & $\begin{array}{c}\text { Penyediaan sarana Telekomunikasi } \\
\text { di lokasi atraksi wisata utama }\end{array}$ & 2018 & Telkomsel \\
\hline 21 & $\begin{array}{l}\text { Pembangunan Desa Pelangi } \\
\text { di Desa Wisata Kolorai }\end{array}$ & 2018 & $\begin{array}{c}\text { Dinpar Kab. Pulau Morotai, } \\
\text { yayasan anak bangsa dan } \\
\text { PT HM Sampoerna }\end{array}$ \\
\hline 22 & $\begin{array}{c}\text { Pembentukan Dewan Kawasan } \\
\text { dan administrator KEK }\end{array}$ & 2014 & pemprov, pemkab, jababeka \\
\hline 23 & $\begin{array}{l}\text { Kegiatan Promosi di Jerman, } \\
\text { Singapura, dan Jepang }\end{array}$ & 2018 & kemenpar dan jababeka \\
\hline
\end{tabular}




\begin{tabular}{|c|c|c|c|}
\hline 24 & $\begin{array}{c}\text { Pembentukan tim percepatan } \\
\text { pembangunan KEK Morotai }\end{array}$ & 2018 & pemkab - jababeka \\
\hline 25 & $\begin{array}{l}\text { Pengadaan DAK Infrastruktur } \\
\text { pariwisata Kab. Pulau Morotai }\end{array}$ & 2018 & dinpar - kemenpar \\
\hline
\end{tabular}

Keterangan:

Sumber: Hasil Analisis Peneliti, 2018

Pemerintah Pusat

Swasta

Pemerintah Daerah

Multi Lembaga

pemerintah daerah dan pemerintah pusat. Dari 18 program yang dilaksanakan oleh sektor pemerintah, pemerintah pusat Republik Indonesia melaksanakan total 14 program dan 4 sisanya dilaksanakan oleh pemerintah daerah Kabupaten Pulau Morotai.

Minimnya pendanaan dan terbatasnya kewenangan yang dimiliki pemerintah daerah menjadi masalah utama untuk pemerintah daerah dapat berperan aktif dalam pembangunan destinasi wisata Kabupaten Pulau Morotai. Selain itu rendahnya kualitas sumber daya manusia dan rentannya instabilitas politik di dalam lingkup politik daerah menjadi salah satu penyebab utama minimnya peran pemerintah daerah Kabupaten Pulau Morotai.

Kondisi seperti ini dapat menjadi hal yang kontraproduktif dalam keberlanjutan pengelolaan destinasi wisata Kabupaten Pulau Morotai. Jika dominasi pembangunan yang dilaksanakan oleh pemerintah pusat terus berlanjut namun tidak dibarengi dengan peningkatan kualitas pemerintah daerah untuk merespon pembangunan yang ada, pada akhirnya aset-aset yang telah dibangun akan menjadi rusak dan tidak berlanjut. Salah satu contoh nyata yang ada di Kabupaten Pulau Morotai adalah terbengkalainya fasilitas-fasilitas yang telah dibangun pada masa Sail Morotai saat ini menjadi rusak dan terbengkalai karena minimnya perawatan yang diakibatkan oleh lambatnya pelimpahan kewenangan dari pemerintah pusat kepada pemerintah daerah di Kabupaten Pulau Morotai.

4.4 Potensi Pergeseran Pusat (core) dan Pinggiran (periphery) dalam konteks destinasi wisata Provinsi Maluku Utara

Pemaknaan terkait konsep core-periphery atau pusat dan pinggiran dalam konteks pariwisata telah dijelaskan oleh Papatheodorou (2006) sebagai pembagian secara spasial terkait perbedaan karakteristik antara pusat kegiatan wisata dan daerah pinggiran dalam suatu negara atau region (provinsi). Secara garis besar karakter dari daerah pusat pariwisata memiliki daya datik yang lebih dari daerah disekitarnya, memiliki akses yang mudah untuk menuju lokasinya, terdapat fasilitas pendukung yang mempermudah kegiatan wisatawan pada lokasi wisata. Sedangkan untuk wilayah pinggiran atau periphery memiliki karakter yang berbanding terbalik dengan pusat.

Dalam konteks destinasi pariwisata Kabupaten Pulau Morotai di dalam kontestasi perwilayahan regional atau dalam wilayah Provinsi Maluku Utara posisi pusat (core) dari destinasi wisata saat ini berada di Kota Ternate. Hal ini berdasarkan dari kondisi aksesibilitas yang mudah dijangkau serta lengkapnya keberadaan atraksi wisata baik alam, budaya, maupun sejarahnya, dan keberadaan amenitas pendukung yang cukup lengkap di Kota Ternate. Sedangkan Kabupaten Pulau Morotai masih menjadi pinggiran (periphery) karena keterbatasan akses serta terbatasnya amenitas di destinasi ini.

Namun apabila dilihat dari perkembangan kawasan yang terbilang pesat sejak penerapan kebijakan kerjasama pemerintah-swasta di Kabupaten Pulau Morotai yang tergambar dari penetapan program KEK Morotai, secara tidak langsung muncul potensi untuk Kabupaten Pulau Morotai dapat menjadi pusat (core) kegiatan wisata di Provinsi Maluku Utara. Besarnya atensi dari pemerintah pusat terhadap pembangunan KEK Morotai yang saat ini difokuskan dalam industri pariwisata dan penyematan status destinasi pariwisata prioritas di Kabupaten ini menjadi 


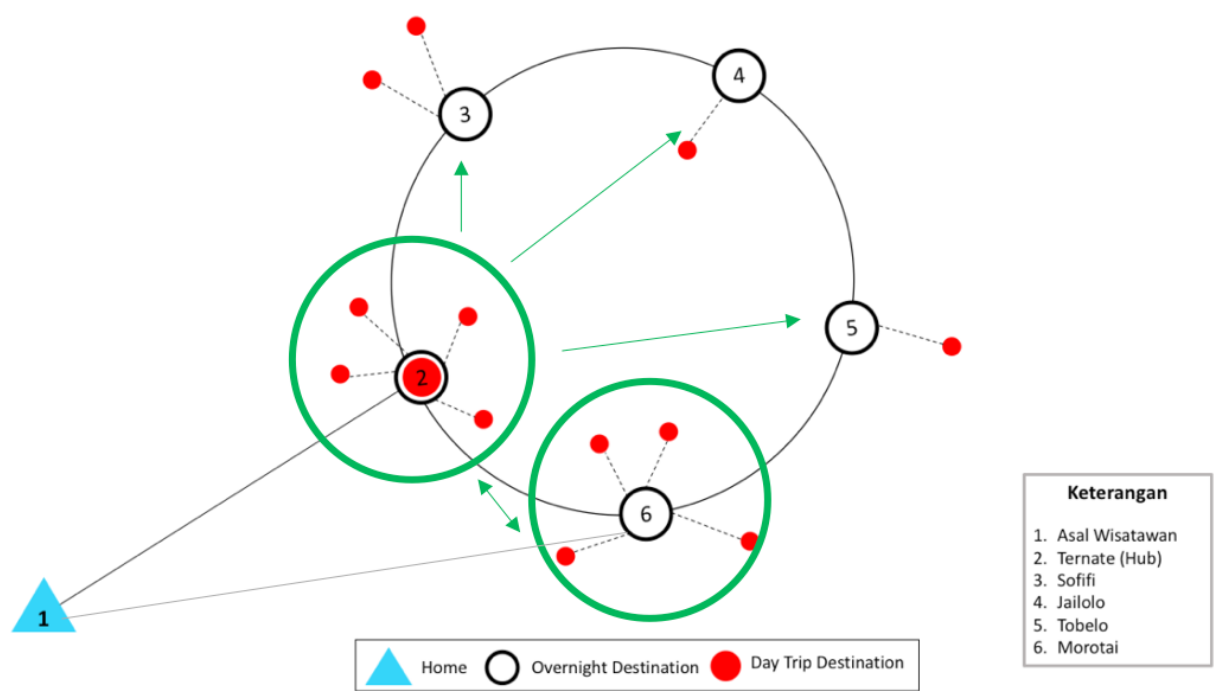

Gambar 4.8: Potensi Pusat (core) dan Pinggiran (periphery) Detinasi Pariwisata di Provinsi Maluku Utara Sumber: Hasil Analisis Peneliti, 2018

titik pancang bagi perkembangan destinasi wisata Kabupaten Pulau Morotai menjadi pusat (core) industri pariwisata di Provinsi Maluku Utara.

Besarnya atensi pemerintah pusat dan daerah serta sektor swasta di Kabupaten Pulau Morotai dapat menjadi embrio bagi perkembangan destinasi wisata ini sebagai pusat (core) industri pariwisata di Provinsi Maluku Utara. Pembuatan bandara sipil dan peningkatan infrastruktur di dalamnya membuat Kabupaten Pulau Morotai memiliki potensi besar untuk dapat diakses langsung oleh pusat pasar wisatawan seperti Jakarta dan Bali. Penguatan akses informasi dan peningkatan sarana akomodasi yang ada di Kabupaten Pulau Morotai juga memperbesar peluang destinasi wisata ini untuk dapat menjadi salah satu pusat (core) industri pariwisata di Provinsi Maluku Utara.

\section{Kesimpulan}

Peran pihak pemerintah dan swasta sudah berjalan dengan optimal dengan terpenuhinya empat dari lima peran dasar pemerintah dan dua dari lima peran dasar sektor swasta. Dalam urusan koordinasi antar lembaga terkait evaluasi dan kontrol terhadap pembangunan, peran sentral dilakukan oleh DN KEK. Dalam pelaksanaannya pembangunan KEK Morotai yang menjadi poros bagi perkembangan destinasi wisata di Kabupaten Pulau Morotai. Pemerintah pusat Republik Indonesia secara keseluruhan masih mendominasi jumlah program yang dilaksanakan terkait pengembangan destinasi wisata Kabuaten Pulau Morotai.

Hal yang menjadi pendorong utama perkembangan destinasi wisata Kabupaten Pulau Morotai salah satunya adalah disematkannya statusstatus strategis nasional terhadap Kabupaten Pulau Morotai serta dengan atensi besar dari pemerintah pusat, daerah dan swasta ada kecenderungan Kabupaten Pulau Morotai untuk menjadi pusat (core) dari kegiatan wisata di Provinsi Maluku Utara yang terlihat dari semakin terbukanya akses menuju Kabupaten Pulau Morotai, peningkatan akses darat yang memudahkan keterjangkauan antar atraksi dan tersematnya status-status nasional di Kabupaten ini.

\section{Daftar Pustaka}

Bjärstig, T., \& Sandström, C. (2017). Public-private partnerships in a Swedish rural context - A policy tool for the authorities to achieve sustainable rural development? Journal of Rural Studies, 49, 58-68.

Butler, R. W. (1980). The Concept of A Tourist Area Life Cycle: Implications for Management of Resources. Canadian Geographer, 24(1), 5-12. 
Derkzen, P., Franklin, A., \& Bock, B. (2008). Examining power struggles as a signifier of successful partnership working: A case study of partnership dynamics. Journal of Rural Studies, 24(4), 458466.

Dinica, V. (2009). Governance for sustainable tourism: A comparison of international and Dutch visions. Journal of Sustainable Tourism, 17(5), 583-603.

Keputusan Bupati Pulau Morotai Tentang Penetapan PT Jababeka Pulau Morotai Sebagai badan Usaha Pembangunan dan Pengelola Kawasan Ekonomi Khusus (KEK) Morotai di Kabupaten Pulau Morotai, Pub. L. No. 538.3/191/PM/2014 (2014). Indonesia.

Lickorish, L. J., Jefferson, A., Bodlender, J., \& Jenkins, C. L. (1994). Developing Tourism Destinastions. Harlow: Longman Group UK Ltd.

Nuryanti, W., \& Hwang, W. G. (Eds.). (2002). Private and Public Sector Partnership In Tourism Development. In East Asia Inter-Regional Tourism Forum (pp. 1-7). Yogyakarta: Gadjah Mada University Press.

Papatheodorou, A. (2006). TALC and The Spatial Implication of Competition. In The Tourism Area Life Cycle. Great Britain: Cromwell Press.

Peraturan Pemerintah Nomor 96 Tahun 2015 Tentang Fasilitas dan Kemudahan Investasi di Kawasan Ekonomi Khusus (2015). Indonesia.
Peraturan Pemerintah Republik Indonesia No 50 Tahun 2011 Tentang Rencana Induk Pembangunan Kepariwisataan Nasional Tahun 2010-2025 (2011). Indonesia.

Peraturan Presiden Republik Indonesia Nomor 58 Tahun 2017 Tentang Perubahan Atas Peraturan Presiden Nomor 3 Tahun 2016 Tentang Percepatan Pelaksanaan Proyek Strategis Nasional (2017). Indonesia.

Pine, R. (2002). Public and Private Sector Partnership: An Inevitable Tool for Sustained Tourism Development in the APEC Region. In Private and Public Sector Partnership in Tourism Development (pp. 11-18).

Sarosa, S. (2012). Penelitian Kualitatif: Dasar-Dasar. Jakarta: PT. Indeks.

Shen, L. Y., Platten, A., \& Deng, X. P. (2006). Role of public private partnerships to manage risks in public sector projects in Hong Kong. International Journal of Project Management,

UNDP. (1997). Governance for Sustainable Human Development - Human Development Report 1997. New York.

Yescombe, E. R. (2007). Public-Private Partnership: Principles of Policy and Finance. Antimicrobial Agents and Chemotherapy (Vol. 58). Burlington: Butterworth-Heineman. 